\title{
Integrating new treatment options into the management of adult ITP
}

\author{
James Granfortuna* \\ Clinical Medicine, Cone Health affiliate of University of North Carolina Chapel Hill Medical Center, USA
}

\begin{abstract}
Treatment of steroid resistant ITP in adults can be challenging in patients who are actively bleeding. The majority of novel therapies that have been developed in the last few years including anti CD 20 monoclonal antibody therapy (Rituximab) and the thrombopoietic growth factors romiplostim and eltombopag, take time to work. Combinations of active agents may accelerate the response rate. Splenectomy and the use of immunosuppressive agents may still have an important role in the acute management. A case of resistant ITP will be discussed in the context of currently available treatment modalities.
\end{abstract}

\section{Introduction}

Immune Thrombocytopenia is an autoantibody mediated blood disorder characterized by both increased platelet destruction and decreased platelet production. The estimated incidence is 9.5 cases per 100,000 population with an estimated 200,000 cases per year in the United States. Median age at presentation is 56 with 2 peaks: age $20-40$ and age over 60 . There is no male/female predominance in adults. The disorder is self-limited in $70-80 \%$ of children.

Immune thrombocytopenia typically presents with bleeding from mucosal surfaces which may include epistaxis, oral mucosal bleeding, or bleeding from the GI or Genitourinary tracts. Critical site bleeding, including the brain, may occur. Spontaneous bruising and a petecchial rash are common presenting complaints. Many patients present with an isolated abnormality found on routine laboratory analysis [1-6].

An International consensus panel redefined the older terminology of ITP (Idiopathic Thrombocytopenic Purpura) into Primary and Secondary Immune Thrombocytopenia. Primary immune thrombocytopenia is a diagnosis of exclusion with isolated thrombocytopenia in the absence of other causes or disorders that may be associated with thrombocytopenia. Secondary immune thrombocytopenia comprises all forms of immune thrombocytopenia except primary ITP. Treatment is targeted to the underlying disease or offending medication/drug and usually has a different natural history compared with primary ITP (Table 1 and Figure 1) [2,7,8].

There are no robust laboratory or clinical parameters available to establish the diagnosis with accuracy. The platelet threshold for diagnosis was changed from $\leq 150,000$ to $\leq 100,000$ based on worldwide epidemiologic observations that there was only a $6.9 \% 10$ year probability that a platelet count in the $100-150,000$ range would get worse over time. Testing for the presence of anti-platelet antibodies has not been informative to date $[9,10]$.

\section{Case History}

The patient is a 40 year old Hispanic woman, originally from Mexico, in excellent health, on no chronic medications, who presented with the sudden onset of gingival bleeding, menorrhagia, and headache.
She did not use alcohol or illicit drugs. She had 6 uncomplicated pregnancies, most recent 3 years prior, and she was still breast feeding. There was no recent travel. No infectious exposures. Previous testing for HIV, RPR, and Hepatitis B surface antigen at time of recent pregnancy was negative. There was no family history of a blood disorder.

\section{Exam}

Obese woman $103 \mathrm{~kg}$. Afebrile

Diffuse gum bleeding in the oropharynx. No cardiac murmur. No lymphadenopathy. No organomegaly. No focal neurologic deficits. No retinal hemorrhages. Optic discs sharp Skin with a diffuse petecchial rash on the trunk and extremities.

\section{Initial Lab}

Hemoglobin 12.3, hematocrit 37\%, MCV 85; WBC 5,800 66 neutrophils, 24 lymphocytes, 8 monocytes, 1 eosinophil, platelet count $<5,000$.

\section{BUN 12, creatinine 0.6}

Uncorrected reticulocyte count $1.2 \%$; bilirubin 0.7 ; LDH 185; haptoglobin 127

Prothrombin time 15.5 seconds (normal up to 15.2); PTT 39 seconds (normal up to 37); fibrinogen $351 \mathrm{mg} \%$; D-dimer $<0.27$.

\section{Review peripheral blood film}

Normochromic, normocytic red cells, no spherocytes, schistocytes, or polychromasia. Less than one platelet per 10 high powered fields.

Platelet count 195,000 7/15/13; 136,000 2/4/14 at time of pregnancy 3 years prior, not repeated since then.

*Correspondence to: James Granfortuna, Associate Professor of Clinical Medicine, Cone Health affiliate of University of North Carolina Chapel Hill Medical Center, USA, Tel: +1 336-832-8062; E-mail: James.Granfortuna@ conehealth.com

Received: July 30, 2018; Accepted: August 10, 2018; Published: August 13, 2018 
Table 1. Differential Diagnosis of ITP. Abbreviations: ITP, idiopathic thrombocytopenic purpura: HIV, human immunodeficiency virus; ESV, Epstein-Barr virus; SLE, systemic lupus erythematosus

\section{Immune \\ Primary}

ITP

Secondary

Drug-induced (eg. quinine)

Post-transfusion purpura

HIV

Hepatitis C

Infectious mononucleosis (EBV virus)

SLE

Crohn's disease

Antiphospholipid antibody syndrome

Chronic lymphocytic leukemia

Lymphoma

$\lg$ A deficiency

Common variable immune deficiency

Sarcoidosis

Non-immune

Hypersplenism

Myelodysplasia

Acute leukemia

Drug-induced marrow suppression (valproic acid, alcohol)

Hereditary thrombocytopenia (MYH-9 mutations)

Microangiopathic hemolytic anemia

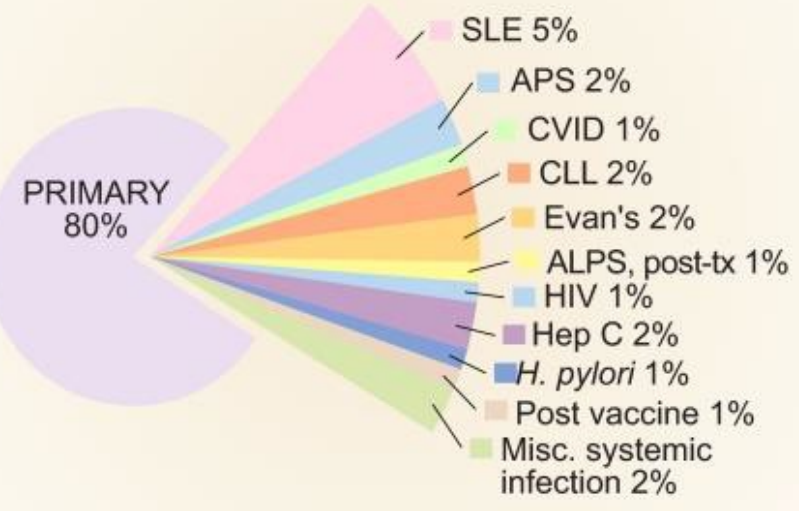

Figure 1. Estimated fraction of the various forms of secondary ITP based on clinical experience of the authors. ALPS indicates autoimmune lymphoproliferative syndrome; posttx, post-bone marrow or solid organ transplant; SLE, systemic lupus erythematosus; APS, antiphospholipid syndrome; CLL, chronic lymphocytic leukemia; CVID, common variable immune deficiency. In the absence of a systematic analysis of the incidence of secondary ITP, the data shown represent our combined assessment based on experience and reading of the literature. Professional illustration by Paulette Dennis [8]

\section{Ancillary Lab Studies}

HIV negative, Hepatitis $C$ antibody and quantitative RNA not detectable; Hepatitis B surface antigen negative, surface antibody positive, e-antibody positive, e-antigen negative in an unvaccinated patient reflecting previous resolved hepatitis B infection.

TSH 3.9; urine pregnancy test negative

\section{Imaging}

Chest X-Ray: no infiltrate or effusion; no adenopathy

CT brain: bilateral curvilinear areas of hyper-attenuation posterior parietal lobes consistent with low grade subarachnoid hemorrhage.

\section{Clinical Course and Management}

This patient presented with both non critical and critical site bleeding. Platelet transfusion indicated in view of critical site bleeding into the brain with early subarachnoid hemorrhage with data showing up to a $40 \%$ response $[11,12,18]$.

Corticosteroids remain the mainstay of initial treatment for newly diagnosed ITP: prednisone $1-2 \mathrm{mg} / \mathrm{kg} / \mathrm{day}$ for 28 days then slowly tapered. An increasing body of data supports the use of pulse, oral, high dose dexamethasone as an alternative [12-14]. In the only prospective, randomized, clinical trial of standard dose prednisone compared with high dose dexamethasone, Yu Wei, et al. demonstrated that dexamethasone $40 \mathrm{mg}$ daily for 4 days resulted in a higher initial response, an approximate doubling of the complete response rate, and a median $50 \%$ shorter time to response with less toxicity compared with standard prednisone (Table 2) [15].

In the actively bleeding patient, alternative steroid dosing with methylprednisolone (Solumedrol) in doses of $30 \mathrm{mg} / \mathrm{kg}$ up to One gram Intravenous for 7 days has been used in conjunction with intravenous immunoglobulin 1 gram/kg x 2 doses [1,4,17]. Anti-D (Rh) globulin 75 micrograms/kg IV over 20 minutes in non splenectomized patients has also been given in conjunction with steroids. Multiple potential mechanisms of action have been proposed for the efficacy of IVIG and/ or anti-D in ITP but the major mechanism is felt to be displacement of antibody coated platelets from Fc receptors in the spleen [17,25]. A bleeding score has been developed to assist in clinical decision making in view of the fact that there is a poor correlation between the absolute platelet count and the propensity to bleed in an individual patient [24].

The patient was given pulse high dose dexamethasone and IVIG. Aygestin, oral estrogen, was initiated to suppress menses. AMICAR was initially given by oral rinse to decrease oral mucosal bleeding and by intravenous to limit intracranial bleeding.

By hospital day 6, there was no platelet response and continued oropharyngeal and vaginal bleeding consistent with steroid refractory, persistent, ITP. Options considered were anti CD-20 monoclonal antibody therapy with Rituximab, thrombopoietin receptor agonists, or splenectomy.

Rituximab targets B lymphocytes resulting in Fc mediated cell lysis with the ability to deplete autoantibody producing B cells active in ITP. There is an overall $40-60 \%$ response rate. Responses are only durable in $20-40 \%$ of patients. A major limitation in the treatment of acute ITP is the slow median time to response of 5.5 weeks. [25-30]. Rituxan plus high dose dexamethasone has been studied as a component of initial therapy but it is unclear whether it's use impacts on the rapidity of response. In a randomized, open label, prospective, phase 3 study in 9 centers in Denmark, 137 newly diagnosed patients with primary ITP with platelet counts less than 25,000 or less than 50,000 with active bleeding, were randomized to high dose dexamethasone or dexamethasone plus Rituximab. The primary endpoint was a sustained

Table 2. Initial CR was a positive indicator of sustained response. 116 patients $(60 \%)$ had baseline platelet count $\leq 10,000$. HD-DXM arm with consistently higher counts after initial response. Bleeding more effectively controlled in the HD-DXM arm [15]

\begin{tabular}{|c|c|c|}
\hline & Prednisone (n=98) & High Dose Dex (n=97) \\
\hline Initial Response & $67 \%$ & $82 \%$ \\
\hline Overall response & $74 \%$ & $85 \%$ \\
\hline Complete Response & $26.8 \%$ & $50.5 \%$ \\
\hline Time to response(days) & $6(2-24)$ & $3(1-9) \mathrm{p}<0.001$ \\
\hline Sustained response & $41.2 \%$ & $40 \%$ \\
\hline
\end{tabular}


platelet count of $\geq 50,000$ at 6 months which was achieved in $58 \%$ of patients in the combined therapy group versus $37 \%$ for dexamethasone alone. Time to response data not reported [31].

A meta-analysis by Chugh et al reviewed 5 eligible trials including 463 non splenectomized patients with ITP who received Rituxan as part of their treatment. In two of the trials, the patients had received no prior treatment. Time to response data not reported. Although complete response rates were higher in the Rituximab treated patients, severe bleeding events did not differ between the two groups [32].

In a small phase IIb study, Choi et al reported that the combination of dexamethasone, low dose Rituximab, and Cyclosporin A given for a single 28 day course resulted in a high response rate when used as first line therapy. 7 of the 20 patients were previously untreated. Overall response was $60 \%$ at 6 months. $76 \%$ of responding patients were relapse free at 24 months. Median time to response was 7.4 days. However, only 3 of 7 patients with newly diagnosed or persistent ITP responded [33].

Thrombopoietin receptor agonists are assuming a major role in the treatment of relapsed refractory ITP. They are the only agents that have been tested in large, randomized, prospective, placebo controlled trials in ITP. Thrombopoietin is the physiologic stimulator of megakaryocyte growth and differentiation acting through $\mathrm{C}$-mpl, the thrombopoietin receptor (Figure 2). Suboptimal platelet production as well as peripheral destruction of platelets combine to cause the thrombocytopenia of ITP. Mechanisms of suboptimal platelet production include: antibodies directed against immature megakaryocytes resulting in decreased platelet production, increased clearance of endogenous thrombopoietin on antibody coated platelets, and inappropriate feedback rise in TPO levels in the face of platelet destruction [16,34-39].

Current American Society of Hematology Guidelines published in 2011 recommend TPO receptor agonists for patients at risk for bleeding after splenectomy (Grade 1B), or to consider use in patients at high risk of bleeding who have failed one line of therapy and who have not had a splenectomy (Grade 2C) [10].

In practice, given the long term efficacy and safety profile of these agents, they are being used more and more before consideration of splenectomy. A drawback to use in the acute bleeding patient is time to response which is on the average of 1-2 weeks. In the clinical trials that led to the approval of Romiplostim, only $25 \%$ of patients responded to the FDA approved starting dose of 1 microgram $/ \mathrm{kg}$ at 1 week with $50 \%$ showing a response after 2 weeks following first dose increase to 2 micrograms/kg [34-42,6,16,19].

Is there a potential to combine TPO receptor agonists with other modalities to accelerate the response rate? Preliminary data using a combination of high dose dexamethasone and Eltrombopag as initial

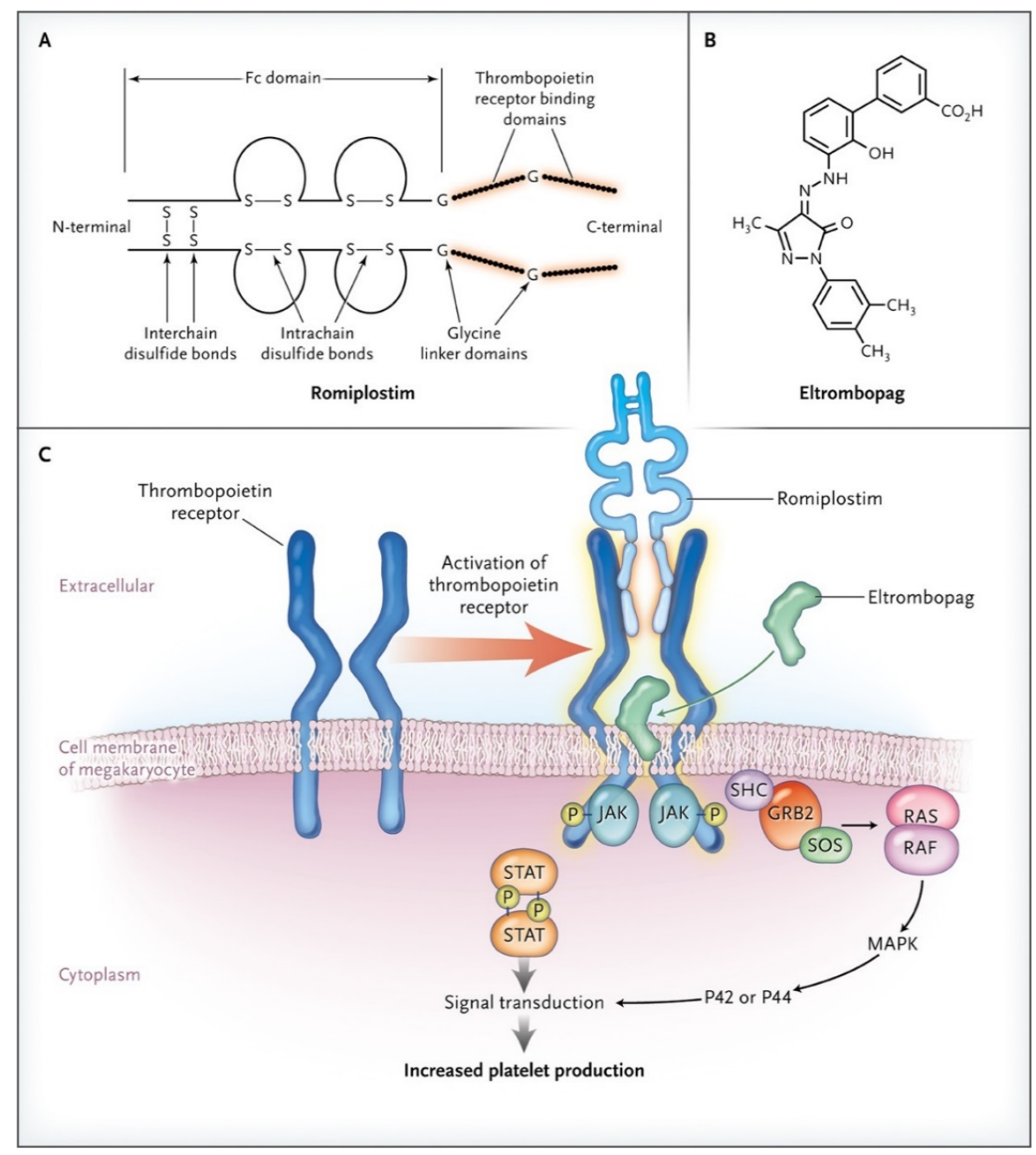

Figure 2. Structure of Romiplostim and Eltrombopag and the Cellular Mechanisms of Action 
therapy are promising. A $100 \%$ overall response rate with $83 \%$ complete responders by 34 days with $75 \%$ ongoing response at 6 months was reported by Gomez-Almaguer [43]. Combinations of TPO receptor agonists with immunosuppressive agents are also under investigation. In a multi-center, randomized, open label study by Zhou, et al. 115 patients with primary ITP and platelet counts $<30,000$ who had failed either steroids, splenectomy, or cyclosporine and were off treatment for at least 4 weeks, were randomized to Rituximab fixed dose of $100 \mathrm{mg}$ weekly $\mathrm{x} 4$ or the combination of Rituximab and thrombopoietin 300 micrograms subcutaneously daily x 14 days. Median time to response with the combination was 7 days (4-28), compared with 28 days (4-90) on the Rituxan only arm. Overall response rate $79 \%$ vs $71 \%(\mathrm{p}=0.36)$, CR rate 45 vs $24 \%(\mathrm{p}=0.026)$ [44] (Table 3$)$.

On hospital day 6, the patient was treated with a combination of Rituximab $375 \mathrm{mg} / \mathrm{m}^{2}$ weekly x 4 and Romiplostim $1 \mathrm{mcg} / \mathrm{kg}$ SQ with weekly dose escalation to $2 \mathrm{mcg} / \mathrm{kg}$ at day 8 then $4 \mathrm{mcg} / \mathrm{kg}$ at day 15 . By day 18 , she had persistent bleeding, increased headache, new onset tinnitus, and blurred vision and no platelet response.

Splenectomy was performed on day 19. There was no increase in platelet count with intra and post op platelet transfusion.

Splenectomy remains the gold standard for treatment of refractory ITP with an approximate $80 \%$ overall response rate and a $50 \%$ durable response past 5 years. Improvement in surgical techniques with the advent of laparoscopic splenectomy has significantly reduced the morbidity and length of hospital stay. Average time to platelet response is 5-7 days $[5,6,10,19,38,44-50]$ [Table 4$]$.

Oral and vaginal bleeding subsided but she complained of increasing tinnitus and headache. Fundoscopic exam now showed bilateral retinal hemorrhages. CT of the brain done on day 23 showed new, subtle, multifocal areas of hemorrhage. K-centra 4 factor clotting factor concentrate administered. 12 hour interval CT brain stable but 24 interval study with subtle areas of increased hemorrhage. A platelet transfusion was given followed immediately by a dose of IV recombinant VIIa. Parenteral AMICAR dose increased. Another course of high dose dexamethasone was initiated [51].

Immunosuppressive drugs still have a role, albeit limited, in acute management of refractory ITP. There are no large, randomized studies of any agent. Commonly used drugs include 6-mercaptopurine, the calcineurin inhibitors Cyclosporin-A and Tacrolimus, alkylating agents such as Cyclophosphamide, vinca alkaloids, vincristine and vinblastine, other immunosuppressive agents such as Azathioprine, and drugs which work by unclear mechanisms such as Danazol and Dapsone. Responses are seen on the average of $50 \%$ of the time. Time to response is, again, an issue with shortest time to response reported for the vincas (5-7 days), followed by cyclophosphamide (7-112 days) (Table 5) $[6,38,41,52,53]$.

On Day 23 Vincristine $2 \mathrm{mg}$ IV was administered.

Bone marrow biopsy showed no additional pathology. Megakaryocyes were present.

On day 25, platelet count began to rise to 7,000: 20 days post initiation of Rituxan/Romiplostim and 7 days post splenectomy, and continued to rise to over one million over the next 7 days with subsequent stabilization at 400,000.

\section{Discussion}

Treatment of the adult patient with acute Primary Immune Thrombocytopenia who is actively bleeding remains a challenge. Combined modality treatment incorporating novel agents is a promising area of study. The ability to achieve a rapid response is crucial. Current literature demonstrates that more rapid and complete responses can be obtained with the use of high dose dexamethasone as initial therapy combined with Intravenous immunoglobulin. Preliminary study also suggests that the combined use of anti CD-20 antibody therapy and thrombopoietin or Thrombopoietin receptor agonists can also

Table 3. Responses and outcomes in the RTX + TPO and RTX groups [44]

\begin{tabular}{|c|c|c|c|}
\hline & RTX $+\operatorname{rhTPO}$ & RTX & $P$ \\
\hline $\mathrm{CR}, \%(\mathrm{n})$ & $45.4(35)$ & $23.7(9)$ & $0.026^{*}$ \\
\hline $\mathrm{PR}, \%(\mathrm{n})$ & $33.8(26)$ & $47.4(18)$ & 0.22 \\
\hline $\mathrm{OR}, \%(\mathrm{n})$ & $79.2(61)$ & $71.1(27)$ & 0.36 \\
\hline NR, \% (n) & $20.8(16)$ & $28.9(11)$ & 0.36 \\
\hline \multicolumn{4}{|l|}{ For patients with an initial response } \\
\hline TTR (days), median (range) & $7(4-28)$ & $28(4-90)$ & $0.004-\dagger$ \\
\hline Duration of response ( $\geq 6 \mathrm{mo}$ ), $\%$ (n) & $67.2(41)$ & $55.6(15)$ & 0.34 \\
\hline Duration of response $(\geq 12 \mathrm{mo}), \%(\mathrm{n})$ & $44.3(27)$ & $29.6(8)$ & 0.24 \\
\hline Duration of response $(\geq 24 \mathrm{mo}), \%(\mathrm{n})$ & $24.6(15)$ & $18.5(5)$ & 0.59 \\
\hline
\end{tabular}

Table 4. Rx Persistent/Chronic ITP [58]

\begin{tabular}{|c|c|c|c|}
\hline Treatment & Time to Respond & Rate of Response & Duration \\
\hline Splenectomy & 1-24 days & $80 \%$ & $\begin{array}{c}60 \% \text { sustained over } \\
5-10 \text { yrs }\end{array}$ \\
\hline Danazol & $3-6 \mathrm{mos}$ & $67 \% \mathrm{CR} / \mathrm{PR}$ & $46 \%$ at $10 \mathrm{yrs}$ \\
\hline IVG & $24-48 \mathrm{hrs}$ & $80 \%$ & 2-4 wks \\
\hline Anti-D Igg & $24-48 \mathrm{hrs}$ & $\begin{array}{l}93 \% \text { initial } \\
68 \% \text { repeat }\end{array}$ & $\begin{array}{c}3-4 \text { wks } \\
43 \% \text { off } \mathrm{Rx}>6 \text { mos }\end{array}$ \\
\hline Rituxan & $1-8$ wks & $\begin{array}{l}60 \% \text { OR } \\
40 \% \text { CR }\end{array}$ & $\begin{array}{l}15-20 \% \\
>3-5 \text { yrs }\end{array}$ \\
\hline \multicolumn{4}{|c|}{ TPO Receptor Agonists } \\
\hline Eltrombopag & $7-15$ days & $>80 \%$ & Up to $5-6$ yrs \\
\hline Romiplostim & $7-28$ days & $79-88 \%$ & Up to 6 years \\
\hline
\end{tabular}


Table 5. Response to immunosuppressive agents. G6PD, glucose 6-phosphate dehydrogenase. * Studies vary in their definition of response. NR: not reported [38]

\begin{tabular}{|c|c|c|c|c|}
\hline Drug & Dose & Response rate $(\%)^{ \pm}$ & Time to response & Selected toxicities \\
\hline 6-mercaptopurine & $50-75 \mathrm{mg} / \mathrm{m}^{2}$ orally once per day & 83 & NR & $\begin{array}{l}\text { Hepatotoxicity, neutropenia, } \\
\text { infection, pancreatitis }\end{array}$ \\
\hline Azathioprine & $\begin{array}{l}1-2 \mathrm{mg} / \mathrm{kg} \text { orally once per day } \\
(\mathrm{maximum} 150 \mathrm{mg} / \mathrm{d})\end{array}$ & $40-60$ & 3-6 mo & $\begin{array}{l}\text { Hepatotoxicity, neutropenia, } \\
\text { infection, pancreatitis }\end{array}$ \\
\hline Cyclosporin A & $\begin{array}{l}5-6 \mathrm{mg} / \mathrm{kg} / \mathrm{d} \text { orally divided into } 2 \\
\text { doses per day (titrate to blood levels } \\
\text { of } 100-200 \mathrm{ng} / \mathrm{mL} \text { ) }\end{array}$ & $30-60$ & $3-4 \mathrm{wk}$ & $\begin{array}{l}\text { Nephrotoxicity, hypertension, } \\
\text { tremor, parathesias, gingival } \\
\text { hyperplasia }\end{array}$ \\
\hline Cyclophosphamide & $\begin{array}{l}0.3-1.0 \mathrm{~g} / \mathrm{m}^{2} \mathrm{IV} \text { repeated once every } \\
2 \text { to } 4 \text { weeks } \times 1 \text { to } 3 \text { doses; } 50- \\
200 \mathrm{mg} \text { orally once per day; after } \\
\text { response has been achieved, dose } \\
\text { can be tapered to } 50 \mathrm{mg}\end{array}$ & $24-85$ & $1-16 \mathrm{wk}$ & $\begin{array}{l}\text { Neutropenia, nausea/vomiting, } \\
\text { infertility, secondary malignancy }\end{array}$ \\
\hline Danazol & $\begin{array}{l}50-800 \mathrm{mg} / \mathrm{d} \text { orally divided into } 2 \text { to } \\
4 \text { doses per day }\end{array}$ & $10-70$ & 3-6 mo & $\begin{array}{l}\text { Hepatotoxicity, virilization, } \\
\text { amenorrhea }\end{array}$ \\
\hline Dapsone & $75-100 \mathrm{mg}$ orally once per day & $40-75$ & $3 \mathrm{wk}$ & $\begin{array}{l}\text { Hemolysis (in patients with } \\
\text { G6PD deficiency), rash, nausea, } \\
\text { methemoglobinuria }\end{array}$ \\
\hline Mycophenolate mofetil & $250-1000 \mathrm{mg}$ orally twice per day & $11-80$ & $4-6 \mathrm{wk}$ & $\begin{array}{l}\text { Headache, diarrhea, nausea, } \\
\text { anorexia, infection }\end{array}$ \\
\hline Vinca alkaloids & $\begin{array}{l}\text { Vincristine: } 1 \text { to } 2 \mathrm{mg} \text { IV once per } \\
\text { week } \times 3 \text { weeks } \\
\text { Vinblastine: } 10 \mathrm{mg} \text { IV once per } \\
\text { week } \times 3 \text { weeks }\end{array}$ & $10-75$ & $5-7 \mathrm{~d}$ & $\begin{array}{l}\text { Peripheral neuropathy, vesication } \\
\text { at infusion site, constipation, fever, } \\
\text { neutropenia }\end{array}$ \\
\hline
\end{tabular}

accelerate the response rate to treatment. More traditional approaches including splenectomy and immunosuppressive agents still have an important role in individual patients. It is unclear whether the early addition of Rituxan plus romiplostim impacted in a positive way on the time to response to splenectomy seen in our patient given the average time to response post splenectomy cited in the literature is 5 to 7 days $[28,29,36,49,50]$.

A number of new areas of investigation are actively being considered or are under study [6,22,38,40-42,54,55].

Since Romiplostim and Eltrombopag act at different sites on the thrombopoietin receptor, combined use could potentially potentiate and accelerate the thrombopoietic effects.

Immunosuppressive drugs that selectively kill plasma cells such as bortezomib, have shown activity in TTP and might be studied in other immune disorders such as ITP.

Novel immunotherapeutics such as fostanitinib targeting Syk (spleen tyrosine kinase) look promising. Syk is a cytoplasmic tyrosine kinase which is activated when $\mathrm{Fc}$ receptors bind to their ligands and promotes phagocytosis of FcyR bound platelets by splenic macrophages. Platelet destruction in ITP is mediated by Syk dependent phagocytosis. Fostanitinib has recently received approved by the FDA in April, 2018 for refractory ITP. C reactive protein also appears to play an important role in $\mathrm{Fc}$ receptor mediated phagocytosis and is a potential therapeutic target [56,57].

As we gain a more sophisticated knowledge of the immune system and lymphocyte regulatory networks, additional avenues of treatment should become available. Antibodies targeting the CD40 - CD154 interaction between $\mathrm{B}$ and $\mathrm{T}$ cells remain under active investigation [6,53-55,58-61].

The potential role of combinations of these agents in the acute management of newly diagnosed remains to be elucidated.

\section{Summary}

An otherwise healthy 40 year old woman presented with acute bleeding in both non critical and critical sites and was diagnosed with primary immune thrombocytopenia. Recent literature suggests that combined modality therapy can result in rapid responses compared with traditional treatments. This patient failed to respond to initial treatment with high dose dexamethasone and intravenous immunoglobulin and continued to bleed. Early addition of combined weekly anti-CD 20 antibody therapy at a standard dose of $375 \mathrm{mg} /$ meter squared and a Thrombopoietin receptor agonist started at 1 microgram $/ \mathrm{kg}$ with weekly dose escalation, did not result in a response by day 13 after initiation and splenectomy was required. There was a delayed response to splenectomy prompting the addition of a single dose of vincristine on day 23. Response was seen on day 25, 20 days after initiation of Rituxan/Romiplostim and 7 days post splenectomy.

Although combined modality therapy, particularly the use of high dose dexamethasone and a TPO agonist with or without Rituximab appears promising, more prospective data is needed to justify use in the patient who presents with major bleeding and early splenectomy remains the standard of care.

\section{References}

1. Cines DB, Bussel JB (2005) How I treat idiopathic thrombocytopenic purpura (ITP) Blood 106: 2244-2251. [Crossref]

2. Bussel J, Tarantino M (2006) Review of therapies for immune thrombocytopenic purpura. Semin Hematol 43: S1-S2. [Crossref]

3. McMillan R (2007) Immune-mediated thrombocytopenias: focus on chronic immune thrombocytopenic purpura. Semin Hematol 44(4 Suppl 5): S1-S2.

4. Bussel JB, Liebman HA, Kuter DJ ITP (2008) Clinical Curriculum Enduring Primer, France Foundation.

5. George JN (2010) Management of immune thrombocytopenia--something old, something new. N Engl J Med 363: 1959-1961. [Crossref]

6. Lambert MP, Gernsheimer TB2 (2017) Clinical updates in adult immune thrombocytopenia. Blood 129: 2829-2835. [Crossref]

7. Cines DB, Liebman H, Stasi R (2009) Pathobiology of secondary immune thrombocytopenia. Semin Hematol 46: S2-14. [Crossref]

8. Cines DB, Bussel JB, Liebman HA, Luning Prak ET (2009) The ITP syndrome pathogenic and clinical diversity. Blood 113: 6511-6521. [Crossref]

9. Provan D, Stasi R, Newland AC (2010) International consensus report on the investigation and management of primary immune thrombocytopenia. Blood 115: 168-186.

10. Neunert C, Lim W, Crowther M (2011) The American Society of Hematology 2011 evidence-based practice guideline for immune thrombocytopenia. Blood 117: 4190-4207. 
11. Carr JM, Kruskall MS, Kaye JA, Robinson SH (1986) Efficacy of platelet transfusions in immune thrombocytopenia. Am J Med 80: 1051-1054. [Crossref]

12. Cheng Y, Wong RS, Soo YO, Chui CH, Lau FY, et al. (2003) Initial treatment of immune thrombocytopenic purpura with high-dose dexamethasone. N Engl J Med 349: 831-836. [Crossref]

13. Andersen JC (1994) Response of resistant idiopathic thrombocytopenic purpura to pulsed high-dose dexamethasone therapy. N Engl J Med 330: 1560-1564.

14. Mazzucconi MG, Fazi P, Bernasconi S (2005) Therapy with high-dose dexamethasone (HD-DXM) in previously untreated patients affected by idiopathic thrombocytopenic purpura: a GIMEMA experience. Blood 109: 1401-1407.

15. Wei Y, Ji X, Wang Y (2016) High-dose dexamethasone vs prednisone for treatment of adult immune thrombocytopenia: a prospective multicenter randomized trial. Blood 127: 296-302.

16. Bussel JB, Kuter DJ (2010) New thrombopoietic agents: introduction. Semin Hematol 47: 211. [Crossref]

17. Godeau B, Chevret S, Varet B (2002) Intravenous immunoglobulin or high-dose methylprednisolone, with or without oral prednisone, for adults with untreated severe autoimmune thrombocytopenic purpura: a randomised, multicentre trial. Lancet Lond Engl 359: 23-29.

18. McCullough J (2010) Overview of platelet transfusion. Semin Hematol 47: 235-242. [Crossref]

19. Ghanima W, Godeau B, Cines DB, Bussel JB (2012) How I treat immune thrombocytopenia: the choice between splenectomy or a medical therapy as a secondline treatment. Blood 120: 960-969.

20. Hansen RJ, Balthasar JP (2002) Effects of intravenous immunoglobulin on platelet count and antiplatelet antibody disposition in a rat model of immune thrombocytopenia. Blood 100: 2087-2093.

21. Scaradavou A, Woo B, Woloski BM, Cunningham-Rundles S, Ettinger LJ, et al. (1997) Intravenous anti-D treatment of immune thrombocytopenic purpura: experience in 272 patients. Blood 89: 2689-2700. [Crossref]

22. Robak T, Windyga J, Trelinski J (2012) Rozrolimupab, a mixture of 25 recombinant human monoclonal $\mathrm{RhD}$ antibodies, in the treatment of primary immune thrombocytopenia. Blood 120: 3670-3676.

23. Newman GC, Novoa MV, Fodero EM, Lesser ML, Woloski BM, et al. (2001) A dose of $75 \mathrm{microg} / \mathrm{kg} / \mathrm{d}$ of i.v. anti-D increases the platelet count more rapidly and for a longer period of time than $50 \mathrm{microg} / \mathrm{kg} / \mathrm{d}$ in adults with immune thrombocytopenic purpura. Br J Haematol 112: 1076- 1078.

24. Khellaf M, Michel M, Schaeffer A, Bierling P, Godeau B (2005) Assessment of a therapeutic strategy for adults with severe autoimmune thrombocytopenic purpura based on a bleeding score rather than platelet count. Haematologica 90: 829-832.

25. Arnold DM, Dentali F, Crowther MA, Meyer RM, Cook RJ, et al. (2007) Systematic review: efficacy and safety of rituximab for adults with idiopathic thrombocytopenic purpura. Ann Intern Med 146: 25-33. [Crossref]

26. Frederiksen H (2015) Rituximab for adult primary immune thrombocytopenia. Lance Haematol 2: e52-53. [Crossref]

27. Ghanima W, Khelif A, Waage A (2015) Rituximab as second-line treatment for adult immune thrombocytopenia (the RITP trial): a multicentre, randomised, double-blind, placebo-controlled trial. Lancet Lond Engl 385: 1653-1661.

28. Hindilerden F, Yönal-Hindilerden I, Yenerel MN, Nalçaci M, Diz-Küçükkaya R (2017) Rituximab Therapy in Adults with Refractory Symptomatic Immune Thrombocytopenia: Long-Term Follow-Up of 15 Cases. Turk J Haematol Off J Turk Soc Haematol 34: 72-80.

29. Patel VL1, Mahévas M, Lee SY, Stasi R, Cunningham-Rundles S, et al. (2012) Outcomes 5 years after response to rituximab therapy in children and adults with immune thrombocytopenia. Blood 119: 5989-5995. [Crossref]

30. Zaja F, Volpetti S, Chiozzotto M (2012) Long-term follow-up analysis after rituximab salvage therapy in adult patients with immune thrombocytopenia. Am J Hematol 87: 886-889.

31. Gudbrandsdottir S, Birgens HS, Frederiksen H (2013) Rituximab and dexamethasone vs dexamethasone monotherapy in newly diagnosed patients with primary immune thrombocytopenia. Blood 121: 1976-1981

32. Chugh S, Darvish-Kazem S, Lim W (2015) Rituximab plus standard of care for treatment of primary immune thrombocytopenia: a systematic review and metaanalysis. Lancet Haematol 2: e75-81.
33. Choi PY, Roncolato F, Badoux X, Ramanathan S, Ho SJ, et al. (2015) A novel triple therapy for ITP using high-dose dexamethasone, low-dose rituximab, and cyclosporine (TT4). Blood 126: 500-503. [Crossref]

34. Bussel JB, Kuter DJ, George JN, McMillan R, Aledort LM, et al. (2006) AMG 531, a thrombopoiesis-stimulating protein, for chronic ITP. N Engl J Med 355: 1672-1681. [Crossref]

35. Bussel JB, Cheng G, Saleh MN, Psaila B, Kovaleva L, et al. (2007) Eltrombopag for the treatment of chronic idiopathic thrombocytopenic purpura. N Engl J Med 357: 2237 2247. [Crossref]

36. Bussel JB (2009) The changing landscape of secondary ITP: introduction. Semin Hematol 46: S1. [Crossref]

37. Kuter DJ, Bussel JB, Lyons RM (2008) Efficacy of romiplostim in patients with chronic immune thrombocytopenic purpura: a double-blind randomised controlled trial. Lance Lond Engl 371: 395-403.

38. Cuker A, Neunert CE (2016) How I treat refractory immune thrombocytopenia. Blood 128: $1547-1554$. [Crossref]

39. Kuter DJ, Rummel M, Boccia R, Macik BG, Pabinger I, et al. (2010) Romiplostim or standard of care in patients with immune thrombocytopenia. $N$ Engl J Med 363: 1889-1899. [Crossref]

40. Perdomo J (2016) Role of romiplostim in splenectomized and nonsplenectomized patients with immune thrombocytopenia. ImmunoTargets Ther 5: 1-7.

41. Mahévas M, Gerfaud-Valentin M, Moulis G (2016) Characteristics, outcome, and response to therapy of multirefractory chronic immune thrombocytopenia. Blood 128: $1625-1630$.

42. Rodeghiero F, Ruggeri M (2015) Treatment of immune thrombocytopenia in adults: the role of thrombopoietin-receptor agonists. Semin Hematol 52: 16-24.

43. Gómez-Almaguer D, Herrera-Rojas MA, Jaime-Pérez JC (2014) Eltrombopag and high-dose dexamethasone as frontline treatment of newly diagnosed immune thrombocytopenia in adults. Blood 123: 3906-3908

44. Zhou H, Xu M1, Qin P, Zhang HY, Yuan CL, et al. (2015) A multicenter randomized open-label study of rituximab plus rhTPO vs rituximab in corticosteroid-resistant or relapsed ITP. Blood 125: 1541-1547. [Crossref]

45. Kojouri K, Vesely SK, Terrell DR, George JN (2004) Splenectomy for adult patients with idiopathic thrombocytopenic purpura: a systematic review to assess long-term platelet count responses, prediction of response, and surgical complications. Blood 104: $2623-2634$

46. Rodeghiero F, Ruggeri M (2008) Is splenectomy still the gold standard for the treatment of chronic ITP? Am J Hematol 83: 91.[Crossref] Rodeghiero F, Ruggeri M (2008) Is splenectomy still the gold standard for the treatment of chronic ITP? Am J Hematol 83: 91. [Crossref]

47. George JN, Vesely SK (2003) Immune thrombocytopenic purpura--let the treatment fit the patient. $N$ Engl J Med 349: 903-905. [Crossref]

48. Chaturvedi S, Arnold DM, McCrae KR (2018) Splenectomy for immune thrombocytopenia: down but not out. Blood 131: 1172-1182. [Crossref]

49. Akwari OE, Itani KM, Coleman RE, Rosse WF (1987) Splenectomy for primary and recurrent immune thrombocytopenic purpura (ITP). Current criteria for patien selection and results. Ann Surg 206: 529-541.

50. DiFino SM, Lachant NA, Kirshner JJ, Gottlieb AJ (1980) Adult idiopathic thrombocytopenic purpura. Clinical findings and response to therapy. Am J Med 69: 430-442.

51. Culic S (2003) Recombinant factor VIIa for refractive haemorrhage in autoimmune idiopathic thrombocytopenic purpura. Br J Haematol 120: 909-910.

52. Reiner A, Gernsheimer T, Slichter SJ (1995) Pulse cyclophosphamide therapy for refractory autoimmune thrombocytopenic purpura. Blood 85: 351-358.

53. Vesely SK, Perdue JJ, Rizvi MA, Terrell DR, George JN (2004) Management of adult patients with persistent idiopathic thrombocytopenic purpura following splenectomy: a systematic review. Ann Intern Med 140: 112-120.

54. Perera M, Garrido T (2017) Advances in the pathophysiology of primary immune thrombocytopenia. Hematology 22: 41-53. [Crossref]

55. Schifferli A, Kühne T (2016) Thrombopoietin receptor agonists: a new immune modulatory strategy in immune thrombocytopenia? Semin Hematol 53 Suppl 1: S31-34. 
56. Kapur R, Heitink-Pollé KMJ, Porcelijn L (2015) C-reactive protein enhances IgGmediated phagocyte responses and thrombocytopenia. Blood 125: 1793-1802.

57. 57. Newland A, Lee E-J, McDonald V, Bussel JB. Fostamatinib for persistent/chronic adult immune thrombocytopenia. Immunotherapy. October 2017. doi:10.2217/imt2017-0097

58. Bussel JB, Lakkaraja M2 (2014) Thrombopoietic agents: there is still much to learn. Presse Med 43: e69-78. [Crossref]
59. Kuwana M, Nomura S, Fujimura K (2004) Effect of a single injection of humanized anti-CD154 monoclonal antibody on the platelet-specific autoimmune response in patients with immune thrombocytopenic purpura. Blood 103: 1229-1236.

60. Patel VL, Schwartz J, Bussel JB (2008) The effect of anti-CD40 ligand in immune thrombocytopenic purpura. Br J Haematol 141: 545-548. [Crossref]

61. Shih A, Nazi I, Kelton JG, Arnold DM (2014) Novel treatments for immune thrombocytopenia. Presse Med 43: e87-95. [Crossref]

Copyright: $₫ 2018$ Granfortuna J. This is an open-access article distributed under the terms of the Creative Commons Attribution License, which permits unrestricted use, distribution, and reproduction in any medium, provided the original author and source are credited. 